\title{
Antiproliferative and cytotoxic effects of purple pitanga (Eugenia uniflora L.) extract on activated hepatic stellate cells
}

\author{
Cristiane C. Denardin ${ }^{1,2}$, Mariana M. Parisi ${ }^{1}$, Leo A. M. Martins ${ }^{1}$, Silvia R. Terra ${ }^{1}$, Radovan Borojevic ${ }^{3}$, \\ Márcia Vizzotto $^{4}$, Marcos L. S. Perry ${ }^{1, \dagger}$, Tatiana Emanuelli ${ }^{5}$ and Fátima T. C. R. Guma ${ }^{1}$ \\ ${ }^{1}$ Departamento de Bioquímica, Universidade Federal do Rio Grande do Sul, Porto Alegre, RS, Brazil \\ ${ }^{2}$ Curso de Farmácia, Universidade Federal do Pampa (UNIPAMPA), Campus Uruguaiana, Uruguaiana, RS, Brazil \\ ${ }^{3}$ Departamento de Histologia e Embriologia, ICB, UFRJ, Rio de Janeiro, RJ, Brazil \\ ${ }^{4}$ Empresa Brasileira de Pesquisa Agropecuária de Clima Temperado, Pelotas, RS, Brazil \\ ${ }^{5}$ Núcleo Integrado de Desenvolvimento em Análises Laboratoriais (NIDAL), Departamento de Tecnologia e Ciência de Alimentos, \\ Universidade Federal de Santa Maria, Santa Maria, RS, Brazil
}

\begin{abstract}
The presence of phenolic compounds in fruit- and vegetable-rich diets has attracted researchers' attention due to their health-promoting effects. The objective of this study was to evaluate the effects of purple pitanga (Eugenia uniflora L.) extract on cell proliferation, viability, mitochondrial membrane potential, cell death and cell cycle in murine activated hepatic stellate cells (GRX). Cell viability by 3-(4,5dimethylthiazolyl)-2,5-diphenyl-2H-tetrazolium bromide (MTT) assay was significantly decreased on cells treated with 50 and $100 \mu \mathrm{g}$ ml ${ }^{-1}$ of purple pitanga extract for 48 and $72 \mathrm{~h}$, and the percentage of dead cell stained with 7-amino-actinomycin D was significantly higher in treated cells. The reduction of cell proliferation was dose dependent, and we also observed alterations on cell cycle progression. At all times studied, GRX cells treated with 50 and $100 \mu \mathrm{g} \mathrm{ml}^{-1}$ of purple pitanga showed a significant reduction in cellular mitochondrial content as well as a decrease in mitochondrial membrane potential. Furthermore, our results indicated that purple pitanga extract induces early and late apoptosis/necrosis and necrotic death in GRX cells. This is the first report describing the antiproliferative, cytotoxic and apoptotic activity for E. uniflora fruits in hepatic stellate cells. The present study provides a foundation for the prevention and treatment of liver fibrosis, and more studies will be carried to elucidate this effect. Copyright @ 2013 John Wiley \& Sons, Ltd.
\end{abstract}

KEY WORDS—liver fibrosis; Eugenia uniflora; cytotoxicity; cell cycle arrest; death cell

\section{INTRODUCTION}

Hepatic fibrosis is a very common disease and results from many forms of chronic liver injuries, for example, persistent viral infections, autoimmune liver diseases, toxins, alcohol and hereditary metal overload. Regardless of causes, liver fibrosis is characterized by increased and altered deposition of newly formed extracellular matrix (ECM) components such as collagen, proteoglycans, fibronectin and hyaluronic acid, leading to the complications of portal hypertension, esophageal varices and hepatic failure. This is a severe disease with high morbidity and mortality, representing a serious worldwide healthcare problem and effective antifibrotic treatments are urgently needed. ${ }^{1}$

Hepatic stellate cells (HSCs), also called Ito cells, vitamin A-storing cells, lipocytes or fat-storing cells, have now been clearly identified as the primary cellular source involved in

*Correspondence to: Cristiane C. Denardin, Departamento de Bioquímica, UFRGS, Ramiro Barcelos, 2600-anexo. Porto Alegre, RS Cep90035-000, Brazil. E-mail: cristiane_denardin@yahoo.com.br

'In memoriam. the pathogenesis of liver fibrosis. During the development of liver fibrosis, stellate cells undergo activation, a process characterized by increased cell proliferation, morphological transformation into myofibroblast-like cells and synthesis of excessive ECM components. ${ }^{2}$ It has been reported that HSCs are involved in the development and regeneration of liver tissue, reorganization of hepatic ECM, development of hepatic fibrosis or cancer cell invasiveness. ${ }^{3}$ The activation and the proliferation of HSC play a key role in fibrogenesis, whereas the apoptosis of HSC is associated with resolution of fibrosis. Inhibiting the activation of stellate cells seems to be an attractive strategy for therapy of liver fibrosis.

Eugenia uniflora L. (Myrtaceae) is a widely distributed tree species in South America, mainly in Brazil, Argentina, Uruguay and Paraguay. The leaves are used in popular medicine as infusion for the treatment of fever, rheumatism, stomach diseases and digestive disorders, as well as hypertension, yellow fever and gout. It may also reduce weight, blood pressure and serve as a diuretic. ${ }^{4,5}$ Its fruit, which is known as pitanga, Brazilian cherry or Suriname cherry, also shows antioxidant activity inhibiting lipid peroxidation and removing free radicals. ${ }^{6-8}$ Recently, pitanga 
leaves were shown to have anti-Trypanosoma activity with low toxicity ${ }^{9}$. Like the leaves, pitanga fruits could also have healthy benefits. In the Brazilian food industry, the pitanga fruit has mostly been used to produce juice, which shows good economic potential due to the consumer appeal arising from its high concentrations of antioxidant compounds, such as anthocyanins, flavonols and carotenoids ${ }^{7,8}$.

The presence of phenolic compounds in fruit- and vegetablerich diets have attracted researchers' attention due to their health-promoting effects, which include lowering the risk of cardiovascular diseases, cancer, or other conditions associated with aging. The biological mechanisms behind these effects include protection against free radicals, free radical-mediated cellular signaling, inflammation, allergies, platelet aggregation, ulcers, viruses, tumors and hepatotoxicity. ${ }^{10}$ Thus, the objective of this study was to evaluate the effects of purple pitanga extract on cell proliferation, viability, mitochondrial membrane potential, cell death and cell cycle in murine HSCs.

\section{MATERIALS AND METHODS}

\section{Preparation of fruit extracts}

Samples of purple-fleshed breeding line of pitanga fruits (E. uniflora) were obtained from harvest 2009/2010 at Embrapa Temperate Climate (Pelotas, Rio Grande do Sul, Brazil, $31^{\circ} 40^{\prime} 47^{\prime \prime} \mathrm{S}, 52^{\circ} 26^{\prime} 24^{\prime \prime} \mathrm{W}, 60 \mathrm{~m}$ ) and immediately frozen. The fruits were sampled searching for a mixture of completely ripe fruits from various plant selections with purple flesh. Three independent samples were collected, frozen at $-18^{\circ} \mathrm{C}$ and transported to the Federal University of Santa Maria.

Fruit extract was prepared from the edible portions of fruits. Briefly, fresh fruit samples were homogenized with an ultraturrax homogenizer for $5 \mathrm{~min}$ in $95 \%$ ethanol $(1: 3, \mathrm{w} / \mathrm{v})$. The homogenates were blended for $30 \mathrm{~min}$, at room temperature, and centrifuged at $1500 \mathrm{~g}$ for $5 \mathrm{~min}$. The supernatant was collected, and the extraction procedure was repeated. The pooled supernatants were concentrated in rotary evaporator at $40^{\circ} \mathrm{C}$. The samples were reconstituted in water and stored at $-80^{\circ} \mathrm{C}$.

Total phenolic content was measured according to the Folin-Ciocalteu method adapted from Swain and Hillis. ${ }^{11}$ The absorbance was measured at $725 \mathrm{~nm}$, and the results were

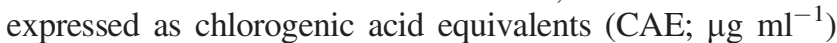
using a chlorogenic acid $\left(0-0.4 \mathrm{mg} \mathrm{ml}^{-1}\right)$ standard curve. The stock concentration of purple pitanga extract was $20.725 \mathrm{mg} \mathrm{CAE} \mathrm{ml}^{-1}$.

\section{Cell culture and treatments}

The immortal HSC line was obtained from livers of $\mathrm{C} 3 \mathrm{H} /$ $\mathrm{HeN}$ mice that were infected by transcutaneous penetration of cercariae from the Schistosoma mansoni BH strain. ${ }^{12}$

The murine HSC cell line, GRX, was established by Borojevic et al. ${ }^{12}$ and kindly provided by the Cell Bank of Rio de Janeiro (HUCFF, UFRJ, RJ). Cells were routinely maintained in Dulbecco's modified minimum essential medium (DMEM; Invitrogen, Carlsbad, CA, USA) supplemented with $5 \%$ fetal bovine serum (GIBCO, Carlsbad, CA, USA) and $2 \mathrm{~g} \mathrm{~L}^{-1}$ HEPES buffer, $\mathrm{pH} 7.4$, lower than $37^{\circ} \mathrm{C}$ and $5 \% \mathrm{CO}_{2}$ conditions. The cells were plated $\left(5 \times 10^{4} \mathrm{ml}^{-1}\right)$ in 12 - or 24 -well plates and cultured for $24 \mathrm{~h}$ to reach $60 \%-70 \%$ of confluence before treatment with purple pitanga. Purple pitanga extract was diluted in culture medium to final concentrations of 5, 50 and $100 \mu \mathrm{g} \mathrm{CAE} \mathrm{ml}^{-1}$ just before use. The GRX cells were treated with the above-mentioned extract concentrations for 24, 48 and $72 \mathrm{~h}$. Each concentration group included three or four wells. The routinely cultured cells were used as normal controls.

\section{Colorimetric MTT assay and cell number count}

MTT (3-(4,5-dimethylthiazolyl)-2,5-diphenyl-2H-tetrazolium bromide) (Sigma Inc., Saint Louis, MO, USA) is a yellow tetrazolium salt that is reduced to purple formazan crystals. The MTT assay is widely used for the assessment of cytotoxicity, cell viability and proliferation studies in cell biology. ${ }^{13}$ Preconfluent GRX cells were incubated with different concentrations of purple pitanga extract for 24,48 and $72 \mathrm{~h}$. Cells were then incubated with $1 \mathrm{mg} \mathrm{ml}^{-1}$ MTT for $2 \mathrm{~h}$ at $37^{\circ} \mathrm{C}$. Purple crystals were dissolved in dimethylsulfoxide (Sigma Inc.). The absorbance was measured using a spectrophotometric microtitre plate reader (Spectra Max M5; Molecular Devices, Sunnyvale, CA, USA) at $570 \mathrm{~nm}$ and $630 \mathrm{~nm}$.

For counting of cell number, preconfluent GRX cells were incubated with different concentrations of purple pitanga extract for 24, 48 and $72 \mathrm{~h}$. Cells were dislodged with $0.25 \%$ trypsin-EDTA and counted using a counting chamber.

\section{Tritiated thymidine incorporation assay}

GRX cells treated, or not, with purple pitanga extract were incubated $\left(24 \mathrm{~h}, 1 \mu \mathrm{Ci} \mathrm{ml}{ }^{-1}\right)$ with $\left[6-{ }^{3} \mathrm{H}\right]$ thymidine $\left(\left[{ }^{3} \mathrm{H}\right] \mathrm{dT}\right)$ (specific activity $23.0 \mathrm{Ci} \mathrm{nmol}^{-1}$; Amersham Biosciences, Hillerod, Denmark). Subsequently, the medium was removed, cells were washed with phosphate-buffered saline (PBS) and $10 \%$ of trichloroacetic acid was added to each well. The cell pellet was then dissolved in $200 \mu \mathrm{L}$ of $0.1 \mathrm{~N} \mathrm{NaOH}$, and the incorporated DNA radioactivity was determined by scintillation counting. ${ }^{14}$ The protein content was measured according to Peterson. ${ }^{15}$

\section{MitoTracker Green}

MitoTracker $^{\circledR}$ Green FM (MTG; Invitrogen) is a probe that becomes fluorescent once it accumulates in the lipid environment of mitochondria, being an important indicator of cellular mitochondrial content. Briefly, after treatment with purple pitanga extracts, GRX cells were washed with PBS before incubation with $100 \mathrm{nM}$ of MTG diluted in free serum DMEM for 30 min under growth conditions. Then cells were washed with PBS, and the MTG fluorescence was measured in a plate spectrofluorometer (Spectra Max M5; Molecular Devices) after exciting at $490 \mathrm{~nm}$ and collecting 
the emission at $516 \mathrm{~nm}$. The results were expressed as relative fluorescence units per microgram of protein.

For confocal images, GRX cells were seeded under coverslips placed on 12-well plates. After treatment, cells were washed with PBS then incubated for $30 \mathrm{~min}$ in the dark with $100 \mathrm{nM}$ of MTG (Invitrogen) diluted in serum free DMEM. Cells were fixed with $2 \%$ of paraformaldehyde for $20 \mathrm{~min}$ at $4{ }^{\circ} \mathrm{C}$ and rewashed with PBS before blades mounting with ProLong Gold antifade reagent (Invitrogen). Images were obtained on FV1000 Olympus Confocal Microscope and deconvolved using the free Image $\mathbf{J}$ analysis software.

\section{Flow cytometry assays}

Cell viability, mitochondrial membrane potential, changes of cell cycle and apoptosis were analyzed by flow cytometry. For all analysis, GRX cells treated or not with the aforementioned extracts were harvested by trypsinization and counted.

The cell viability was evaluated using 7-amino-actinomycin D (7-AAD; BD Bioscience, San Jose, CA, USA). The cells $\left(1 \times 10^{6}\right.$ cells $\left.\mathrm{ml}^{-1}\right)$ were incubated with $5 \mu \mathrm{L}(0.25 \mu \mathrm{g})$ of $7-\mathrm{AAD}$ at room temperature for $10 \mathrm{~min}$, washed in PBS and resuspended for FL3-H analysis.

Tetrachloro-1,1,3,3-tetraethylbenzimidazol-carbocynineiodine ( $\mathrm{JC} 1$; BD Bioscience) is a fluorescent dye that exists as green-emitting monomers at low mitochondrial membrane potential, or as red-emitting aggregates when mitochondrial membrane potential increases. ${ }^{16}$ The cells $\left(1 \times 10^{6}\right.$ cells ml $\left.^{-1}\right)$ were incubated with $500 \mu \mathrm{L}$ of JC1 solution for $15 \mathrm{~min}$, washed two times with buffer according to the manufacturer's manual and analyzed for FL1-H and FL2-H.

For cell cycle analysis, the cells were washed in PBS and resuspended in $400 \mu \mathrm{L}\left(1 \times 10^{6}\right.$ cells $\left.\mathrm{ml}^{-1}\right)$ of cell cycle solution (3.5 mM trisodium citrate, $0.5 \mathrm{mM}$ Tris, $0.1 \%$ Nonidet, $100 \mu \mathrm{g} \mathrm{ml}^{-1}$ RNAse A, $50 \mu \mathrm{g} \mathrm{ml}^{-1}$ propidium iodide) and incubated in the dark at room temperature for $15 \mathrm{~min}$. The DNA content was then analyzed.

Apoptosis was analyzed with annexin-V FITC conjugate kit (Invitrogen). The cells were washed with PBS and resuspended at $1 \times 10^{6}$ cells $\mathrm{ml}^{-1}$ in annexin- $\mathrm{V}$ binding buffer (10 mM HEPES/NaOH, pH 7.4, $140 \mathrm{mM} \mathrm{NaCl}$, $\left.2.5 \mathrm{mM} \mathrm{CaCl}_{2}\right) ; 10^{5}$ cells ml $^{-1}(100 \mu \mathrm{L} /$ tube $)$ were incubated with $5 \mu \mathrm{L}$ of Annexin-V FITC and $5 \mu \mathrm{g} \mathrm{ml}^{-1}$ of propidium iodine, mixed and incubated for $15 \mathrm{~min}$ at room temperature in the dark. Four hundred microlitres of binding buffer was added to each tube and cells were analyzed for FL1-H and FL3-H.

The detection of caspase activation was performed using the "CaspACE, FITC-VAD-fmk In Situ Marker" (Promega, Madison, USA). Briefly, $1 \times 10^{6}$ cells were washed in PBS, suspended in $100 \mu \mathrm{L}$ staining solution containing $50 \mu \mathrm{M}$ of the fluorescein isothiocyanate conjugate of $\mathrm{z}-\mathrm{VAD}-\mathrm{fmk}$ (FITC-VAD-fmk) and incubated for $20 \mathrm{~min}$ at $30^{\circ} \mathrm{C}$ in the dark. Then cells were washed once and suspended in PBS, and cells were analyzed for FL1-H.

All analyses were performed using a FACScan Calibur flow cytometer (BD Bioscience) equipped with a blue laser emitting $488 \mathrm{~nm}$ and a red laser emitting $633 \mathrm{~nm}$.

\section{Statistical analysis}

Data were reported as mean $\pm \mathrm{SD}$. Results were analyzed by one-way ANOVA followed by Tukey's test $(P<0.05)$. All analyses and graphical were performed using the statistical software GraphPad Prism 5 for Windows (GraphPad Software Inc., version 5.01, San Diego, USA).

\section{RESULTS}

Purple pitanga extract inhibits cell growth and interferes with cell viability in GRX cells

The effects of purple pitanga extract on cell viability were assessed by MTT assay and flow cytometry 7-AAD stain (Figures $1 \mathrm{~A}$ and $1 \mathrm{~B}$ ). The results show that the cell viability by MTT assay was significantly decreased on cells treated with $50 \mu \mathrm{g} \mathrm{ml}^{-1}$ of purple pitanga extract for $72 \mathrm{~h}$ and on cells treated with $100 \mu \mathrm{g} \mathrm{ml}^{-1}$ for 48 and $72 \mathrm{~h}$ (Figure 1A). Furthermore, the percentage of dead cell stained with 7-AAD was significantly higher in cells treated with $50 \mu \mathrm{g} \mathrm{ml}^{-1}$ of purple pitanga extract for 48 and $72 \mathrm{~h}$ and $100 \mu \mathrm{g} \mathrm{ml} \mathrm{m}^{-1}$ of purple pitanga extract at all times studied (Figure 1B). 7-AAD is used as a cell viability stain: cells with compromised membranes will stain with 7-AAD, whereas live cells with intact cell membranes will remain dark.

The antiproliferative effects of purple pitanga extract were assessed by cell counting and thymidine incorporation assay (Figures 1C and 1D). The reduction of cell proliferation was dose dependent at the cell counting assay and the cells treated with $100 \mu \mathrm{g} \mathrm{ml}^{-1}$ of purple pitanga extract visually not increased in three days of treatment (Figure 1C). This effect was confirmed by the thymidine incorporation assay, where the decrease in GRX cell proliferation was dose and time dependent (Figure 1D). In three days of treatment, all concentrations of purple pitanga extract significantly decreased GRX cell proliferation.

Impaired mitochondrial membrane potential and decreased mitochondrial content induced by purple pitanga extract in GRX cells

Mitochondrial content was assessed by MTG probe (Figures 2A and 2C), which is now commonly used for measurement of mitochondrial shape changes, mass or swelling. ${ }^{16,17}$ Mitochondrial content was significantly reduced in GRX cells treated with 50 and $100 \mu \mathrm{g} \mathrm{ml}^{-1}$ of purple pitanga at all times studied (Figures $2 \mathrm{~A}$ and 2C).

The mitochondrial membrane potential was measured by JC1 (Figures 2B and 2D), which is a dye that changes its fluorescence emission from red to green when mitochondria loss its membrane polarization. The results show that JC-1 exists as aggregates within the mitochondria (red) in control cells. In cells treated with 50 (for $72 \mathrm{~h}$ ) and $100 \mu \mathrm{g} \mathrm{ml}^{-1}$ of purple pitanga extract (for 48 and $72 \mathrm{~h}$ ), JC-1 exists primarily as the monomeric form (green) within the cytoplasm, indicating less membrane potential related to the reduced mitochondrial content as shown by MTG (Figures 2B and 2D). 

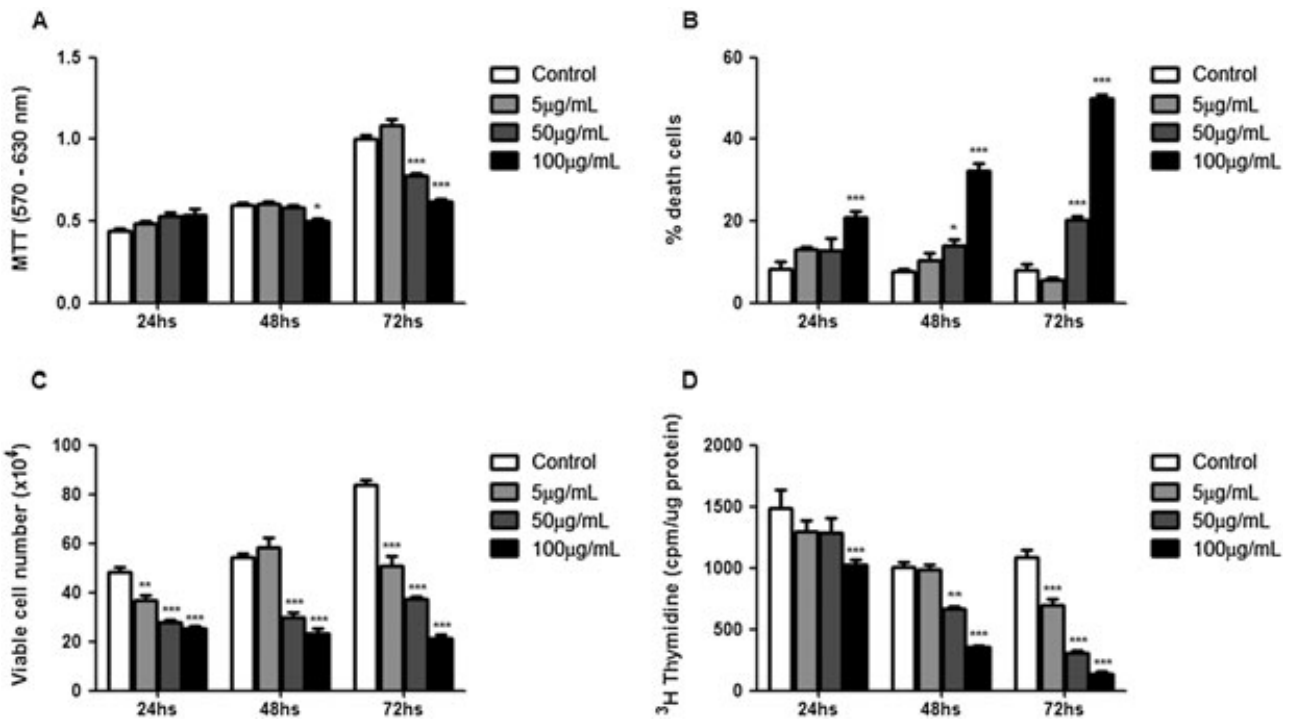

Figure 1. Effect of purple pitanga (Eugenia uniflora L.) extract on cell viability and proliferation in GRX cells. The cells were treated with 5, 50 and $100 \mu \mathrm{g}$ CAE ml ${ }^{-1}$ concentrations of purple pitanga extract for 24,48 and $72 \mathrm{~h}$. Cell viability measured by (A) MTT assay and (B) 7-AAD analyzed by flow cytometry. Cell proliferation measured by $(C)$ cell counting and (D) $[3 \mathrm{H}] \mathrm{dT}$ incorporation assay. Values are shown as mean $\pm \mathrm{SD}$ of three independent experiments. $* P<0.05, * * P<0.01$ and $* * * P<0.001$ versus untreated control cells; $278 \times 168 \mathrm{~mm}(96 \times 96 \mathrm{DPI})$

\section{Purple pitanga extract affect the cell cycle progression in GRX cells}

The effects of purple pitanga extract on cell proliferation could be due to its actions on cell cycle (Figure 3). Cell cycle progression in GRX cells treated with purple pitanga extract was analyzed by flow cytometry. The cells treated with 50 and $100 \mu \mathrm{g} \mathrm{ml}^{-1}$ of purple pitanga extract for $24 \mathrm{~h}$ showed a $13 \%$ increase in the number of GRX cells in $\mathrm{G}_{0} \mathrm{G}_{1}$ phase and reduction in the $\mathrm{S}$ phase (Figure 3). Although the increase in the $G_{0} G_{1}$ phase persists with time, only treatment with $50 \mu \mathrm{g} \mathrm{ml}^{-1}$ of purple pitanga extract was significant at 48 and $72 \mathrm{~h}$. Furthermore at $72 \mathrm{~h}$, the treatment with 50 and $100 \mu \mathrm{g} \mathrm{ml}^{-1}$ of purple pitanga leads to an increase of cells in the $G_{0} G_{1}$ phase with a concomitant decrease in $S$ phase and the disappearance of $G_{2} M$ phase. The $100-\mu \mathrm{g} \mathrm{ml}^{-1}$ treatment also results in an increase in apoptotic sub- $G_{1}$ population (Figure 3 ). The sub- $G_{1}$ population represents cells with significant DNA damage that was confirmed by the annexin V/PI assay.

\section{Apoptotic effect of purple pitanga extract in GRX cells}

Purple pitanga extract-induced apoptosis in GRX cells was examined and confirmed by annexin V and PI staining, using FACS analysis. We did not observe an increase in apoptosis in cells treated for 24 and $48 \mathrm{~h}$. However, the percentage of necrotic cells increased significantly in cells treated with 50 and $100 \mu \mathrm{g} \mathrm{ml}^{-1}$ for $48 \mathrm{~h}$ (Figure 4A). As shown in Figure 4B, the percentage of viable cells was reduced from $91.07 \%$ to $51.58 \%$ by the higher treatment with purple pitanga extract for $72 \mathrm{~h}$. The largest apoptotic and necrotic effects were observed on cells treated for $72 \mathrm{~h}$, where we observed a significant increase in early apoptosis in cells treated with $5 \mu \mathrm{g} \mathrm{ml}^{-1}$, an increase in late apoptosis and necrosis in cells treated with $50 \mu \mathrm{g} \mathrm{ml}^{-1}$ and an increase in early and late apoptosis in cells treated with $100 \mu \mathrm{g} \mathrm{ml}^{-1}$ of purple pitanga extract. These results indicate that purple pitanga extract induces the apoptotic process in early and late stages and induces necrosis in GRX cells.

\section{DISCUSSION}

Brazil features the largest biodiversity in the world; however, only $8 \%$ have been studied in search for bioactive compounds 9. E. uniflora L. is often used as a food and in folk medicine due to many biological activities. Their leaves are used in infusions or decoctions in popular medicine to treat hypercholesterolemia, gout, hypertension, digestive disease, rheumatism, inflammations, fever and hepatic disease and as a diuretic, antimicrobial and antioxidant 4,6,18-22. However, we found no study evaluating the effects of the fruits of this plant that also have a high antioxidant activity. Several phytoconstituents of E. uniflora leaves have been isolated, such as flavonoids myricitrin, quercetin and quercetin 3-ramnoside, and steroids, mono- and triterpenoid compounds, tannins, anthraquinones, phenols, cineol and essential oils ${ }^{23,24}$ and several phenolic compounds were identified in fruits, such as myricetin and quercetin derivatives, quercitrin, isoquercitrin and cyanidin derivatives, among others, which may contribute differentially to the antioxidant capacity (our unpublished observations) ${ }^{7}$.

The liver has an extraordinary capacity to regenerate and restore from damage tissue after chemical or mechanical injury. As previously mentioned, in response to liver injury, HSC lose vitamin A droplets and undergo significant morphological and functional changes, a complex process defined as "activation," leading to the acquisition of a 

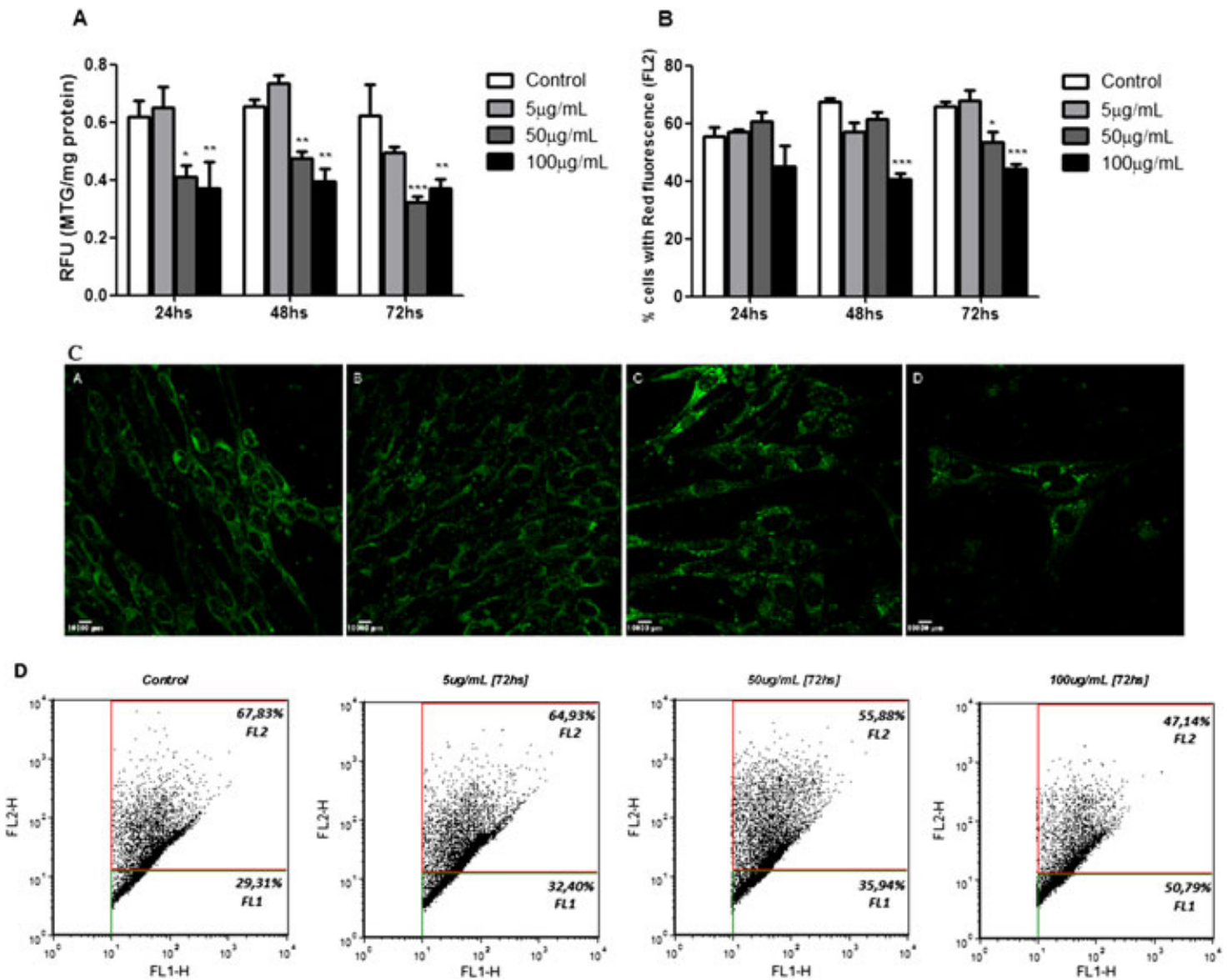

Figure 2. Purple pitanga (Eugenia uniflora L.) extract alter mitochondrial membrane potential and mitochondrial mass in GRX cells. The cells were treated with 5, 50 and $100 \mu \mathrm{g} \mathrm{CAE} \mathrm{ml}{ }^{-1}$ concentrations of purple pitanga extract for 24, 48 and $72 \mathrm{~h}$. (A and C) Mitochondrial mass assessed by MTG fluorescent probe. (C) A, control untreated cells; B, $53 \mu \mathrm{g} \mathrm{ml}^{-1}$; C, $503 \mu \mathrm{g} \mathrm{ml}^{-1}$; D, $1003 \mu \mathrm{g} \mathrm{ml}{ }^{-1}$. (B and D) Mitochondrial membrane potential measured by JC1 fluorescent probe FL2 channel shows the red-emitting aggregates formed when mitochondrial membrane potential increases. Values are shown as mean \pm SD of three independent experiments. $* P<0.05, * * P<0.01$ and $* * * P<0.001$ versus untreated control cells; $282 \times 235 \mathrm{~mm}(96 \times 96 \mathrm{DPI})$
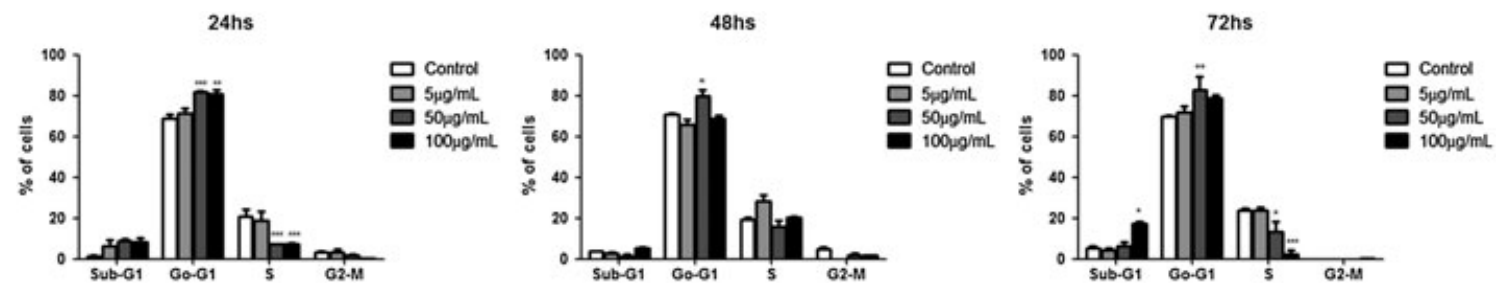

Figure 3. The effect of purple pitanga (Eugenia uniflora L.) extract on cell cycle progression in GRX cells. The cells were treated with 5, 50 and $100 \mu \mathrm{g}$ CAE $\mathrm{ml}^{-1}$ concentrations of purple pitanga extract for 24,48 and $72 \mathrm{~h}$. Values are shown as mean \pm SD of three independent experiments. $* P<0.05, * * P<0.01$ and $* * * P<0.001$ versus untreated control cells; $406 \times 81 \mathrm{~mm}(96 \times 96 \mathrm{DPI})$

myofibroblast-like cell phenotype and to the excessive production of collagen. Fibrosis resolution refers to pathways that either drive the stellate cell to apoptosis or contribute to their reversion to a more quiescent phenotype. ${ }^{2}$ Thus, the inhibition of HSC activation and proliferation and the induction of the apoptosis of activated HSC have been proposed as potential antifibrotic strategies.

Our results show that the treatment with purple pitanga extract reduced the proliferation and viability of GRX cells. Kawada et al. ${ }^{14}$ demonstrated that resveratrol, quercetin and
$\mathrm{N}$-acetylcysteine inhibited the proliferation of rat stellate cells and their expression of smooth muscle $\alpha$-actin. Similarly, cyanidin 3-glucoside inhibited the cell proliferation of HSC isolated from rat liver induced by a pro-oxidant agent. This effect appeared to be directly related to the inhibition of type I collagen synthesis rather than to the antioxidant activity. ${ }^{25}$ Previous studies from our research group evaluating the profile of phenolic compounds in purple pitanga extract observed the presence of various flavonoids and anthocyanins, and cyanidin 3-glucoside and quercetin derivatives were 

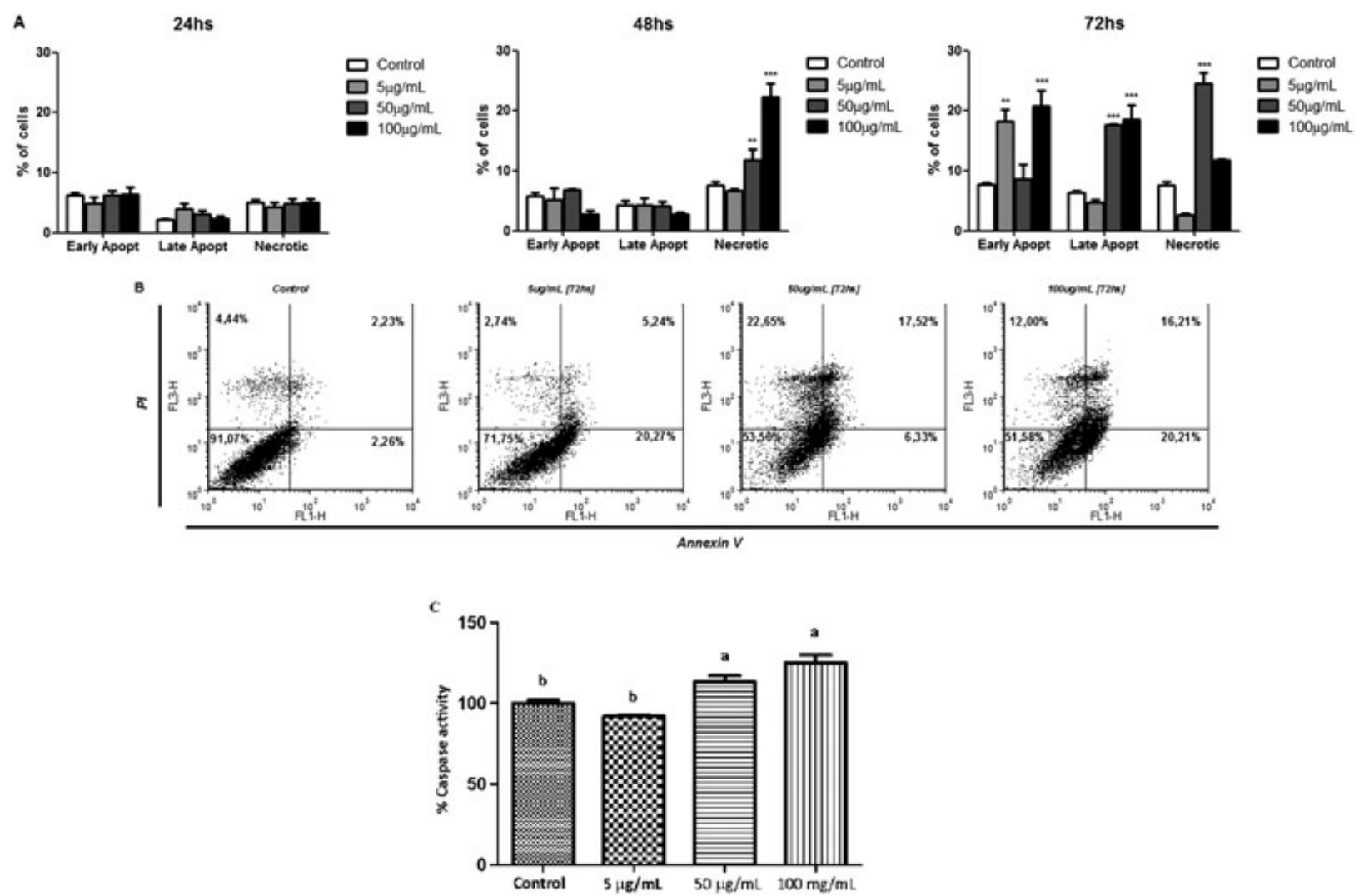

Figure 4. Apoptotic effects of purple pitanga (Eugenia uniflora L.) extract in GRX cells. The cells were treated with 5, 50 and $100 \mu \mathrm{g} \mathrm{CAE} \mathrm{ml} \mathrm{l}^{-1}$ concentrations of purple pitanga extract for 24, 48 and $72 \mathrm{~h}$. (A) Apoptosis analyzed with annexin-V FITC Conjugate Kit. (B) Nonapoptotic cells: annexin-V negative and PI negative; early apoptotic cells: annexin-V positive and PI negative; late apoptotic cells: annexin-V positive and PI positive; necrotic cells: annexin-V negative and PI positive. (C) Detection of caspase activation using the "CaspACE, FITC-VAD-fmk In Situ Marker" for $72 \mathrm{~h}$; different letters indicate statistical difference. Values are shown as mean $\pm \mathrm{SD}$ of three independent experiments. $* P<0.05$, $* * P<0.01$ and $* * * P<0.001$ versus untreated control cells; $400 \times 274 \mathrm{~mm}(96 \times 96 \mathrm{DPI})$

found at significant amounts. In addition, preliminary results evaluating the type I collagen expression by RT-PCR has observed a significant reduction in GRX cells treated with 5 and $50 \mu \mathrm{g} \mathrm{ml}^{-1}$ of purple pitanga extract (data not shown). Thus, the antiproliferative effect and the reduced viability observed in the present study may be related to the effect of these phenolic compounds in the resolution of fibrosis and may be related to alterations on cell cycle progression and/or activation of cell death via apoptosis and/or necrosis, as we observed.

Because DNA content increases due to the cell proliferation, the potential of stellate cells to proliferate can be assessed as the increased number of the cells in the $S$ and $G_{2} / M$ phases as well as the decreased number in the $\mathrm{G}_{0} \mathrm{G}_{1}$ phase. Our data suggest that purple pitanga extract has an inhibitory effect on GRX cell proliferation, which may be associated with $\mathrm{G}_{0} \mathrm{G}_{1}$ cell cycle arrest. Studies using several kinds of popular herbs of Japanese medicine also found antiproliferative effects by inducing arrest at the $\mathrm{G}_{0} \mathrm{G}_{1}$ phase in the cell cycle of HSCs. $^{26,27}$ Furthermore, studies using isolated phenolic compounds as quercetin and baicalein also found similar results. Quercetin arrested $\mathrm{HSCs}_{\text {at }} \mathrm{G}_{1}$ phase with a selective decrease in the cellular levels of cyclin D1 a cell cycle-related protein of $\mathrm{G}_{1}$ phase. ${ }^{14,28}$ Many flavonoids alter the expression and activities of numerous enzymes involved in the regulation of cell cycle in cancer cell lines. ${ }^{29-31}$ Thus, the cell cycle arrest observed in this study may be attributed to the presence of phenolic compounds in the purple pitanga extract, like quercetin and other flavonoids that may be acting individually or synergistically.

Mitochondria are membrane-enclosed organelles found in most eukaryotic cells. In addition to supplying cellular energy, mitochondria are involved in a range of other processes, such as signaling, cellular differentiation, cell death, and the control of the cell cycle and cell growth. ${ }^{32}$ The respiratory chain pumps protons to the intermembrane space, generating an electrochemical gradient across the mitochondrial inner membrane consisting of mitochondrial membrane potential and a minor $\mathrm{pH}$ gradient. Mitochondrial membrane potential is a widely used bioenergetic parameter affecting multiple mitochondrial functions including ATP synthesis, $\mathrm{Ca}^{++}$sequestration, protein import, mitochondrial fusion, mitochondrial autophagy and the generation of reactive oxygen species. ${ }^{33}$ Our results demonstrate a reduction of mitochondrial membrane potential measured by $\mathrm{JC} 1$ fluorescent probe accompanied by decrease of mitochondrial mass observed by MTG. These results can be related with the antiproliferative effect of purple pitanga extract, the increase of 
cytotoxicity observed by 7-AAD and mainly the increase in early and late apoptosis and necrosis observed in this study.

Mitochondrial depolarization is frequently attributed to mitochondrial respiratory dysfunction. ${ }^{16}$ Furthermore, the opening of mitochondrial membrane permeability transition pores results in a collapse of mitochondrial membrane potential and cessation of adenosine triphosphate synthesis. In addition, the release of intermembrane proteins, such as apoptosis-inducing factor and endonuclease $G$ and their translocation to the nucleus, leads to nuclear DNA fragmentation. Together, these events trigger cell death. Alternatively, the release of cytochrome $\mathrm{c}$ and other proapoptotic factors from mitochondria can promote caspase activation and apoptotic cell death. ${ }^{34}$ Thus, the marked reduction in mitochondrial mass and mitochondrial membrane potential observed in cells treated with purple pitanga extract could be caused by activation of apoptosis and necrosis pathways as observed as an increase in sub-G1 cell populations and annexin $\mathrm{V}$ and PI positive cells.

As previously mentioned, the inhibition of HSCs activation and proliferation and the induction of apoptosis have become potentially important for the prevention and treatment of hepatic fibrosis. Apoptosis is a normal physiological process during development and cellular differentiation. "Programmed cell death" can be triggered experimentally by a variety of physical or chemical stressors. It can be induced by a range of stimuli such as ultraviolet irradiation, hyperthermia and cytotoxic chemotherapy. In contrast to necrosis, apoptosis is a well-regulated physiological process, and any disturbance of the balance between cell proliferation and cell death maintained by apoptosis can result in serious diseases. The property of many flavonoids to alter the expression and activities of numerous enzymes involved in the regulation of apoptosis may be the reason for the observed cytostatic properties and the induction of apoptosis in many cell types. Myricetin, quercetin, isorhamnetin and kaempferol have been shown to induce apoptosis in human acute myeloid leukemic cells (HL-60). ${ }^{31}$ Furthermore, neferine and rosmarinic acid reduced cell proliferation and induced apoptosis in rat HSC line HSC-T6. ${ }^{35,36}$ According to Ding et al. ${ }^{35}$, neferine induces the apoptosis of HSC-T6 cells by increasing the activation of caspase 3 , that is, by mitochondrial pathway. Therefore, the marked increase in apoptosis and necrosis observed in cells treated with purple pitanga extract for $72 \mathrm{~h}$ may be related to the mitochondrial apoptotic route because it also observed a reduction in mitochondrial mass and membrane potential. Moreover, we observed by flow cytometry an intense activation of caspases, which reinforces this theory. Further studies are being conducted to elucidate the exact route that is being activated.

In the present study, we demonstrated that purple pitanga extract leads to an inhibition of proliferation, alterations on cell cycle progression and GRX cells apoptosis. This is the first report on the antiproliferative, cytotoxic and apoptotic activity for E. uniflora fruits in HSCs. Further studies are being conducted to determine the molecular mechanisms underlying the cell cycle arrest and the apoptosis induced by purple pitanga extract.
In conclusion, our results suggest that the inhibitory effect of purple pitanga extract on HSCs was promoted by the reduction on proliferation probably via $G_{0} G_{1}$ cell cycle arrest and cytotoxicity observed with a consequent increase in apoptosis and necrosis. Our results also suggest that apoptosis is triggered via mitochondria mainly due to the activation of caspases and the reduction in mitochondrial membrane potential and cellular mitochondria content. The present study provides a foundation for the prevention and treatment of liver fibrosis, and more studies in vivo will be carried to elucidate this effect.

\section{CONFLICT OF INTEREST}

The authors have declared that there is no conflict of interest.

\section{ACKNOWLEDGEMENTS}

The authors acknowledge the Conselho Nacional de Desenvolvimento Científico e Tecnológico (CNPq) for their financial support and the Embrapa Clima Temperado for their collaboration and supply of fruit samples.

\section{REFERENCES}

1. Wynn TA. Cellular and molecular mechanisms of fibrosis. J Pathol 2008; 214(2): 199-210.

2. Friedman SL. Hepatic stellate cells: protean, multifunctional, and enigmatic cells of the liver. Physiol Rev 2008; 88(1): 125-72.

3. Sato M, Suzuki S, Senoo H. Hepatic stellate cells: unique characteristics in cell biology and phenotype. Cell Struct Funct 2003; 28(2): 105-12.

4. Schmeda-Hirschmann G et al. Preliminary pharmacological studies on Eugenia uniflora leaves: xanthine oxidase inhibitory activity. J Ethnopharmacol 1987; 21(2): 183-6.

5. Alice CB et al. Screening of plants used in south Brazilian folk medicine. J Ethnopharmacol 1991; 35(2): 165-71.

6. Velazquez E et al. Antioxidant activity of Paraguayan plant extracts. Fitoterapia 2003; 74(1-2): 91-7.

7. Celli GB, Pereira-Netto AB, Beta T. Comparative analysis of total phenolic content, antioxidant activity, and flavonoids profile of fruits from two varieties of Brazilian cherry (Eugenia uniflora L.) throughout the fruit developmental stages. Food Res Int 2011; 44(8): 2442-2451.

8. Bagetti $\mathrm{M}$ et al. Physicochemical characterization and antioxidant capacity of pitanga fruits (Eugenia uniflora L.). Ciência e Tecnologia de Alimentos 2011; 31: 147-154.

9. Santos KK et al. Anti-Trypanosoma cruzi and cytotoxic activities of Eugenia uniflora L. Exp Parasitol 2012; 131(1): 130-2.

10. Dillard CJ, German JB. Phytochemicals: nutraceuticals and human health. J Sci Food Agric 2000; 80(12): 1744-1756.

11. Swain T, Hillis WE. The phenolic constituents of Prunus domestica. I.-The quantitative analysis of phenolic constituents. J Sci Food Agric 1959; 10(1): 63-68.

12. Borojevic R et al. Establishment of a continuous cell line from fibrotic schistosomal granulomas in mice livers. In Vitro Cell Dev Biol 1985; 21(7): 382-90.

13. Stockert JC et al. MTT assay for cell viability: Intracellular localization of the formazan product is in lipid droplets. Acta Histochem 2012; 114(8): 785-96.

14. Kawada $\mathrm{N}$ et al. Effect of antioxidants, resveratrol, quercetin, and $\mathrm{N}$-acetylcysteine, on the functions of cultured rat hepatic stellate cells and Kupffer cells. Hepatology 1998; 27(5): 1265-74. 
15. Peterson GL. A simplification of the protein assay method of Lowry et al. which is more generally applicable. Anal Biochem 1977; 83(2): 346-56.

16. Wikstrom JD, Twig G, Shirihai OS. What can mitochondrial heterogeneity tell us about mitochondrial dynamics and autophagy? Int J Biochem Cell Biol 2009; 41(10): 1914-27.

17. Presley AD, Fuller KM, Arriaga EA. MitoTracker Green labeling of mitochondrial proteins and their subsequent analysis by capillary electrophoresis with laser-induced fluorescence detection. J Chromatogr B Analyt Technol Biomed Life Sci 2003; 793(1): 141-50.

18. Holetz FB et al. Screening of some plants used in the Brazilian folk medicine for the treatment of infectious diseases. Mem Inst Oswaldo Cruz, 2002; 97(7): 1027-31.

19. de Souza GC et al. Ethnopharmacological studies of antimicrobial remedies in the south of Brazil. J Ethnopharmacol 2004; 90(1): 135-43.

20. Arai I et al. Improving effects of the extracts from Eugenia uniflora on hyperglycemia and hypertriglyceridemia in mice. J Ethnopharmacol 1999; 68(1-3): 307-14.

21. Schapoval EE et al. Evaluation of some pharmacological activities of Eugenia uniflora L. J Ethnopharmacol 1994; 44(3): 137-42.

22. Consolini AE, Baldini OA, Amat AG. Pharmacological basis for the empirical use of Eugenia uniflora L. (Myrtaceae) as antihypertensive. J Ethnopharmacol 1999; 66(1): 33-9.

23. Amorim AC et al. Antinociceptive and hypothermic evaluation of the leaf essential oil and isolated terpenoids from Eugenia uniflora L. (Brazilian Pitanga). Phytomedicine 2009; 16(10): 923-8.

24. Wazlawik E et al. Analysis of the role of nitric oxide in the relaxant effect of the crude extract and fractions from Eugenia uniflora in the rat thoracic aorta. J Pharm Pharmacol 1997; 49(4): 433-7.

25. Bendia E et al. Effect of cyanidin 3-O-beta-glucopyranoside on hepatic stellate cell proliferation and collagen synthesis induced by oxidative stress. Dig Liver Dis 2005; 37(5): 342-8.
26. Kayano K et al. Inhibitory effects of the herbal medicine Sho-saiko-to (TJ-9) on cell proliferation and procollagen gene expressions in cultured rat hepatic stellate cells. J Hepatol 1998; 29(4): 642-9.

27. Chor SY et al. Anti-proliferative and pro-apoptotic effects of herbal medicine on hepatic stellate cell. J Ethnopharmacol 2005; 100(1-2): 180-6.

28. Inoue T, Jackson EK. Strong antiproliferative effects of baicalein in cultured rat hepatic stellate cells. Eur J Pharmacol 1999; 378(1): 129-35.

29. Casagrande F, Darbon JM. Effects of structurally related flavonoids on cell cycle progression of human melanoma cells: regulation of cyclin-dependent kinases CDK2 and CDK1. Biochem Pharmacol 2001; 61(10): 1205-15.

30. Wang IK, Lin-Shiau SY, Lin JK. Induction of apoptosis by apigenin and related flavonoids through cytochrome c release and activation of caspase-9 and caspase-3 in leukaemia HL-60 cells. Eur J Cancer 1999; 35(10): 1517-25.

31. Rusak G, Gutzeit HO, Müller JL. Structurally related flavonoids with antioxidative properties differentially affect cell cycle progression and apoptosis of human acute leukemia cells. Nutr Res 2005; 25(2): 143-155.

32. McBride HM, Neuspiel M, Wasiak S. Mitochondria: more than just a powerhouse. Curr Biol 2006; 16(14): R551-60.

33. Nicholls DG, Ward MW. Mitochondrial membrane potential and neuronal glutamate excitotoxicity: mortality and millivolts. Trends Neurosci 2000; 23(4): 166-74.

34. Nicholls DG. Mitochondrial membrane potential and aging. Aging Cell 2004; 3(1): 35-40.

35. Ding $\mathrm{H}$ et al. Neferine inhibits cultured hepatic stellate cell activation and facilitates apoptosis: A possible molecular mechanism. Eur J Pharmacol 2011; 650(1): 163-9.

36. Zhang JJ et al. Rosmarinic acid inhibits proliferation and induces apoptosis of hepatic stellate cells. Biol Pharm Bull 2011; 34(3): 343-8. 